\title{
HUBUNGAN ANTARA KECERDASAN LOGIS MATEMATIS DENGAN HASIL BELAJAR MATEMATIKA
}

\author{
Astriyati Lodhong Milsan \\ STKIP Citra Bakti Ngada, Nusa Tenggara Timur \\ Astriyati.lodhong@gmail.com \\ Melkior Wewe \\ STKIP Citra Bakti Ngada, Nusa Tenggara Timur \\ melkiorwewe1@gmail.com
}

\begin{abstract}
Abstrak
Penelitian ini bertujuan untuk mengetahui hubungan yang signifikan antara kecerdasan logis matematis dengan hasil belajar matematika siswa. Penelitian ini dirancang dalam bentuk penelitian ex-post facto. Metode yang digunakan adalah metode korelasional. Populasi pada penelitian ini adalah siswa kelas V SD Gugus Bajawa I yang berjumlah 121 siswa. Pengambilan sampel dilakukan dengan teknik simple random sampling dengan jumlah sampel sebanyak 93 siswa. Metode pengumpulan data dalam penelitian ini adalah dengan menggunakan tes. Untuk menguji hipotesis penelitian dengan menghitung koefisien antara X dan Y dengan menggunakan rumus Korelasi Product Moment. Dari hasil perhitungan uji hipotesis diperoleh nilai rxy hitung $=0,866$ kemudian dibandingkan dengan rtabel pada taraf signifikan 0,05 diperoleh nilai rtabel untuk $\mathrm{dk}=91 \mathrm{dan} \alpha=$ 0,05 adalah $=0,207$, oleh karena itu rxy hitung > rtabel maka H1 diterima. Besarnya hubungan atau korelasi antara kecerdasan logis matematis dengan hasil belajar matematika setelah dianalisis diperoleh korelasi $r=0,866$ dengan koefisien determinasi sebesar $75 \%$. Dengan demikian disimpulkan bahwa terdapat hubungan yang signifikan antara kecerdasan logis matematis dengan hasil belajar matematika pada siswa Kelas V SD Gugus bajawa I Tahun Ajaran 2016/2017.
\end{abstract}

Kata Kunci: Kecerdasan Logis Matematis, Hasil Belajar Matematika

\begin{abstract}
This study aims to know the significant correlation between mathematical logical intelligence and students mathematics learning outcome. This study was designed in the form of ex-post facto research. The method used was the correlation method. The population in this study was the fifth grade students of 1 Bajawa cluster primary school numbered in 121 students. The simple random sampling was used for the sampling with its sample in amount of 93 students. The method of data collection in this study was test method. For testing the study hypothesis by counting the coefficient between $\mathrm{X}$ and $\mathrm{Y}$ used the formula of moment product correlation. From the count result on the hypothesis got that the value of rxy count > rtable then compared rtable at the significant standard 0,05 got the value of rtable for $\mathrm{dk}=91$ and $\alpha=0,05$ is 0,207 . Because rxy count $>$ rtable, so that $\mathrm{H} 1$ accepted. The result of the correlation between mathematical logical intelligence and the mathematics learning outcome after analyzed got the correlation $r=0,866$ with the determinate coefficient in the amount of $75 \%$. From that result can be concluded that there is a significant correlation between mathematical logical intelligence and mathematics learning outcome at the fifth grade students of 1 Bajawa cluster primary school school year 2016/2017.
\end{abstract}

Keywords: Mathematical Logical Intelligence, Math Learning Outcome

\section{Pendahuluan}

Pendidikan merupakan faktor penting dalam tatanan kehidupan. Pendidikan yang baik tentunya dapat menghasilkan sumber daya manusia yang berkualitas, yang mampu bersaing di era globalisasi. Dalam UU RI No. 2 Tahun 1989 dijelaskan bahwa pendidikan Nasional bertujuan mencerdaskan kehidupan bangsa dan mengembangkan manusia yang seutuhnya, yaitu manusia yang beriman dan bertaqwa kepada Tuhan Yang Maha Esa dan berbudi pekerti luhur, memiliki pengetahuan dan keterampilan, kesehatan jasmani dan rohani, kepribadian yang mantap dan mandiri serta rasa tanggung jawab kemasyarakatan dan kebangsaan.

Pendidikan di Indonesia semakin hari semakin rendah kualitasnya. Salah satu faktor rendahnya kualitas pendidikan di Indonesia adalah kurangnya peran guru dalam menggali pengetahuan siswa. Para pendidik sering memaksakan kehendak siswa tanpa memperhatikan kebutuhan, bakat, dan minat yang dimiliki siswanya. Para pendidik seharusnya memperhatikan kebutuhan anak bukan memaksakan sesuatu yang membuat anak merasa tidak nyaman. Kurangnya kreatifitas guru dalam melaksanakan suatu pembelajaran juga menjadi faktor rendahnya kualitas pendidikan.

Di dalam UU No. 20 Tahun 2003 Pasal 5 ayat (1) menjelaskan bahwa setiap warga negara mempunyai hak yang sama untuk memperoleh pendidikan yang bermutu; dan ayat (5) setiap warga negara berhak mendapat kesempatan meningkatkan pendidikan sepanjang hayat. Dengan ketentuan dan sampai batas umur tertentu, dalam setiap sistem pendidikan nasional biasanya ada kewajiban belajar. Hal ini berarti bahwa secara formal, setiap 
warga negara harus menjadi peserta didik, paling tidak biasanya pada jenjang pendidikan tingkat dasar. Dalam pembelajaran di Sekolah Dasar (SD), setiap mata pelajaran memiliki tingkat kesukaran yang berbeda-beda. Oleh karena itu, diperlukan kemampuan untuk memperoleh, mengelolah dan memanfaatkan ilmu pengetahuan dan teknologi secara proporsional.

Kemampuan ini membutuhkan pemikiran yang sistematis, logis, dan kritis yang dapat dikembangkan melalui peningkatan mutu pendidikan. Hal yang paling menentukan untuk tercapainya pendidikan yang berkualitas adalah proses pembelajaran yang dilaksanakan. Kemampuan ini membutuhkan pemikiran yang sistematis, logis, dan kritis yang dapat dikembangkan melalui pembelajaran matematika.

Matematika merupakan suatu disiplin ilmu yang mempunyai kekhususan dibanding dengan disiplin ilmu lainnya yang harus memperhatikan hakekat matematika dan kemampuan siswa dengan belajar. Russel (dalam Uno dan Kuadrat, 2009: 108) mendefinisikan bahwa matematika sebagai suatu studi yang dimulai dari pengkajian bagian-bagian yang sangat dikenal menuju arah yang tidak dikenal. Arah yang dikenal itu tersusun baik (konstruktif), secara bertahap menuju arah yang rumit (kompleks) dari bilangan bulat ke bilangan pecah, bilangan rill ke bilangan kompleks, dari penjumlahan dan perkalian ke diferensial dan integral, dan menuju matematika yang lebih tinggi. Pakar lain, Soedjadimemandang bahwa "matematika merupakan ilmu yang bersifat abstrak, aksiomatik, dan deduktif".

Berdasarkan pendapat tersebut, pembelajaran Matematika di kelas, hendaknya ditekankan pada keterkaitan antara konsep-konsep Matematika dengan pengalaman anak sehari-hari. Selain itu, menerapkan kembali konsep Matematika yang telah dimiliki anak pada kehidupan sehari-hari atau pada bidang lain sangat penting dilakukan, hal itulah pembelajaran matematika memerlukan media pembelajaran guna mengaitkan konsep matematika dengan kehidupan sehari-hari.

Pembelajaran matematika adalah proses interaksi antara guru dan siswa yang melibatkan pengembangan pola berpikir dan mengolah logika pada suatu lingkungan belajar yang sengaja diciptakan oleh guru dengan berbagai metode agar program belajar matematika tumbuh dan berkembang secara optimal dan siswa dapat melakukan kegiatan belajar secara efektif dan efisien.

Hasil observasi awal diperoleh hasil bahwa hasil belajar siswa masih rendah, khususnya pada pelajaran matematika. Hal ini, disebabkan karena masih banyak siswa yang merasa matematika sebagai mata pelajaran yang sulit, tidak menyenangkan, bahkan momok yang menakutkan. Ini mungkin disebabkan oleh proses pembelajaran yang belum efektif.

Marti (dalam Sundayana, 2015: 2) mengemukakan bahwa, meskipun matematika dianggap memiliki tingkat kesulitan yang tinggi, namun setiap orang harus mempelajarinya karena merupakan sarana untuk memecahkan masalah sehari-hari. Pemecahan masalah tersebut meliputi penggunaan informasi, penggunaan pengetahuan tentang bentuk dan ukuran, penggunaan pengetahuan tentang menghitung dan yang terpenting adalah kemampuan melihat serta menggunakan hubungan-hubungan yang ada. Berdasarkan permasalahan-permasalahan di atas, penulis dapat menyimpulkan bahwa berbagai masalah tersebut mengindikasikan kecerdasan logika matematika siswa yang belum berfungsi secara maksimal serta rendahnya hasil belajar matematika siswa. Untuk mengatasi hal tersebut diperlukan sebuah kemampuan berpikir mengenai logika matematika yang mendukung. Kodisi rendahnya hasil belajar matematika siswa sebenarnya bukan masalah yang serius, tetapi guru belum menempuh cara-cara alternatif untuk meningkatkan hasil belajar siswa, dengan menggali dan meningkatkan kecerdasan matematis siswa.

Pada dasarnya setiap anak didik memiliki kecerdasan yang berbeda-beda. Demikian pula untuk kecerdasan yang berhubungan dengan matematis ini. Mereka pasti memilikinya, tetapi kurang optimal karena pengembangannya terhambat oleh berbagai kondisi. Namun, dengan rangsangan belajar yang intensif dan menarik sehingga menyenangkan, kecerdasan matematis ini bisa dilatih dan ditingkatkan.

Tingkat kecerdasan yang dimiliki oleh setiap siswa berbeda-beda. Oleh karena itu hasil belajar yang diperoleh juga berbeda-beda. Pada mata pelajaran matematika misalnya, hasil belajar yang diperoleh siswa berbeda-beda. Hal ini terjadi karena tingkat kecerdasan logika matematika yang dimiliki siswa dapat mempengaruhi hasil belajar matematika siswa tersebut. Tingkat kecerdasan logika matematika yang tinggi dapat membantu siswa untuk meraih hasil belajar matematika yang tinggi pula yang didukung dengan proses belajar yang menyenangkan.

Inteligensi (kecerdasan) bukanlah suatu yang bersifat kebendaan, melainkan suatu fiksi ilmiah untuk mendeskripsikan perilaku individu yang berkaitan dengan kemampuan intelektual dan pembentukan logika 
berpikir kreatif terhadap anak untuk mendalami suatu materi. Logika dalam pengertian ini adalah berkaitan dengan argumen-argumen, yang mempelajari metode-metode dan prinsip-prinsip untuk menunjukan keabsahan (sah atau tidaknya) suatu argumen, khususnya yang dikembangkan melalui penggunaan metode-metode matematika dan simbol-simbol matematika dengan tujuan untuk menghindari makna ganda dari bahasa yang biasa kita gunakan sehari-hari. Logic Smart adalah kemampuan berpikir dalam penalaran atau berhitung, seperti kemampuan dalam mengamati masalah secara logis, ilmiah, dan matematis. Logic Smart menjadikan anak mempunyai kemampuan dalam mengenali pola-pola suatu kejadian dan susunanya, mereka senang bermain dengan angka, ingin mengetahui bagaiman cara kerja suatu benda (Winataputra, $2007: 56$ ).

Pada tahun 1980-an Howard Gardner (dalam Hariwijaya dan Surya, 2007: 12) berpendapat bahwa manusia memiliki spektrum intelektual yang kaya, yang ditunjukan dalam suatu gambar kognisi yang jelas. Gardner mengemukakan bahwa semua manusia memiliki sembilan kecerdasan, yaitu kecerdasan linguistik, kecerdasan logika matematika, kecerdasan spasial-visual, kecerdasan kinestetika tubuh, kecerdasan musikal, kecerdasan interpersonal, kecerdasan intra personal, dan inteligensi natural, dan kecerdasan eksistensial. Kesembilan inteligensi ini disebut multiple intelligence (inteligensi majemuk).

Mathematic-logical intelligence is defined as someone's ability to implicate components such as mathematical calculation and measurement, logical thinking, problemsolving, deductive and inductive approach, and accuracy of pattern and its relation as well the implications (Wewe, 2017). Kecerdasan matematis-logis adalah kepekaan pada memahami pola-pola logis atau numeris, dan kemampuan mengolah alur pemikiran yang panjang. Hal ini berkaitan dengan kemampuan berhitung, menalar, dan berpikir logis, memecahkan masalah (Chatib, 2012: 56).

Pengaruh inteligensi matematika dengan kesuksesan dalam hidup sangat tinggi. Inteligensi matematika mempengaruhi seseorang dalam pemahaman kerja. Misalnya membaca laporan keuangan, membaca data-data matematis, menangkap dan memanfaatkan peluang berdasarkan hitungan matematis dan sebagainya. Kecerdasan logika matematika merupakan inteligensi yang meliputi kemampuan menjumlahkan secara matematis, berpikir secara logis, mampu berpikir secara deduktif dan induktif serta ketajaman dalam membuat pola-pola dan hubungan-hubungan yang logis. Inteligensi ini berhubungan erat dengan ilmu pengetahuan dan logika. Beberapa kemampuan tersebut diperlukan dalam belajar dan menyelesaikan soal-soal matematika. Sehingga dalam pembelajaran matematika hubungan antara kecerdasan logika matematika dengan hasil belajar matematika siswa sangat erat.

Hasil belajar merupakan tolak ukur yang digunakan untuk menentukan tingkat keberhasilan siswa dalam mengetahui dan memahami suatu mata pelajaran, biasanya dinyatakan dengan nilai yang berupa huruf atau angkaangka. Hasil belajar dapat berupa keterampilan, nilai dan sikap setelah siswa mengalami proses belajar. Melalui proses belajar mengajar diharapkan siswa memperoleh kepandaian dan kecakapan tertentu serta perubahanperubahan pada dirinya.

Dalam sistem pendidikan nasional, rumusan tujuan pendidikan, baik tujuan kurikuler maupun tujuan instruksional, menggunakan klasifikasi hasil belajar dari Benyamin Bloom yang secara garis besar membaginya menjadi tiga ranah, yakni ranah kognitif, ranah afektif, dan ranah psikomotoris. (1) Ranah kognitif berkenaan dengan hasil belajar intelektual yang terdiri dari enam aspek, yakni pengetahuan atau ingatan, pemahaman, aplikasi, analisis, sintesis, dan evaluasi. (2) Ranah afektif berkenaan dengan sikap yang terdiri dari lima aspek, yakni penerimaan, jawaban atau reaksi, penilaian, organisasi, dan internalisasi. (3) Ranah psikomotoris berkenaan dengan hasil belajar keterampilan dan kemampuan bertindak. Hasil belajar adalah sesuatu yang diperoleh setelah melakukan kegiatan belajar. Hasil belajar diperoleh setelah diadanya evaluasi, Mulyasa (2007) menyatakan bahwa "Evaluasi hasil belajar pada hakekatnya merupakan suatu kegiatan untuk mengukur perubahan perilaku yang telah terjadi”. Hasil belajar ditunjukan dengan prestasi belajar yang merupakan indikator adanya perubahan tingkah laku siswa.

Hasil belajar matematika adalah tingkat penguasaan kognitif siswa terhadap materi pelajaran matematika setelah mengalami proses pembelajaran dalam jangka waktu tertentu, berupa nilai yang dituangkan dalam bentuk angka yang diperoleh dari hasil menjawab tes prestasi belajar matematika yang diberikan pada akhir pelajaran. Hasil yang dimaksud adalah kecakapan nyata yang diperoleh siswa setelah belajar, bukan kecakapan potensial, sebab hasil belajar ini dapat dilihat secara nyata yang berupa nilai setelah mengerjakan suatu tes. Tes yang digunakan untuk menentukan hasil belajar sering diistilahkan dengan tes hasil belajar. Sesuai dengan pendapat 
Bloom hasil belajar siswa meliputi ketiga ranah yakni ranah kognitif, avektif, dan psikomotor yang berubah sebagai akibat pengalaman dan proses belajar siswa.

Masalah dalam penelitian ini adalah "Apakah Terdapat Hubungan yang Signifikan antara Kecerdasan Logis Matematis dengan Hasil Belajar Matematika pada Siswa Kelas V SD GUGUS Bajawa I Tahun Ajaran 2016/2017" Tujuan yang ingin dicapai dalam penelitian ini adalah untuk mengetahui hubungan antara kecerdasan logis matematis dengan hasil belajar matematika pada siswa kelas V SD Gugus Bajawa I Tahun Ajaran 2016/2017.

\section{Metode Penelitian}

Jenis penelitian ini merupakan jenis penelitian ex post facto yang meneliti hubungan sebab akibat yang tidak dimanipulasi atau diberi perlakuan (dirancang dan dilaksanakan) oleh peneliti (Sukmadinata, 2012: 55). Penelitian hubungan sebab akibat dilakukan terhadap program, kegiatan, atau kejadian yang telah berlangsung atau telah terjadi. Adanya hubungan sebab akibat didasarkan atas kajian teoretis, bahwa suatu variabel disebabkan atau dilatarbelakangi oleh variabel tertentu atau mengakibatkan variabel tertentu. Seperti antara variabel X dan Y dimana variabel $\mathrm{X}$ adalah kecerdasan logis matematis sedangkan variabel Y adalah hasil belajar siswa.

Penelitian ini bertujuan untuk mengetahui hubungan yang signifikan antara kecerdasan logis matematis dengan hasil belajar matematika siswa. Populasi dalam penelitian ini adalah seluruh siswa Kelas V SD Gugus Bajawa I yang berjumlah 121 siswa. Pengambilan sampel dilakukan dengan teknik simple random sampling dengan jumlah sampel sebanyak 93 siswa. Metode pengumpulan data kecerdasan logis matematis dan hasil belajar matematika dalam penelitian ini adalah dengan menggunakan tes. Setelah data dalam penelitian terkumpul maka selanjutnya dilakukan analisis data. Dalam menganalisis ini digunakan metode analisis statistik deskriptif kuantitatif. Dalam penerapan analisis data statistik deskriptif kualitatif, data yang diperoleh dari hasil penelitian dianalisis dan disajikan dalam bentuk (1) tabel distribusi frekuensi, (2) menghitung rata-rata (mean), (3) menghitung median, (4) menghitung modus, (5) menyajikan data ke dalam bentuk grafik histogram, (6) menyajikan data ke dalam bentuk kurva. Dari nilai akhir yang diperoleh selanjutnya dianalisis menggunakan statistik kuantitatif untuk mengetahui ada tidaknya kontribusi kecerdasan logis matematis terhadap hasil belajar matematika.

\section{Hasil Penelitian dan Pembahasan}

Hasil penelitian menunjukkan bahwa tingkat kecerdasan logika matematika siswa kelas V SD Gugus Bajawa I sebagian besar berada pada kategori sangat tinggi dengan nilai rata-rata 83,30, begitu pula dengan hasil belajar matematika siswa yang berada pada kategori sangat tinggi dengan nilai rata-rata 85,94. Dengan demikian, dapat disimpulkan bahwa tingkat kecerdasan logika matematika dan hasil belajar matematika siswa kelas V SD Gugus Bajawa I berada pada kategori sangat tinggi.

Berdasarkan hasil analisis data, diperoleh besarnya hubungan atau korelasi antara kecerdasan logika matematika dengan hasil belajar matematika rxy hitung $=0,866$ dan rtabel untuk $\mathrm{dk}=91 \mathrm{dan} \alpha=0,05$ adalah 0,207 , sehingga rxy hitung > rtabel, dan nilai signifikansi hasil analisis SPSS adalah $=0,000$ lebih kecil dari nilai taraf signifikansi $0,05(0,000<0,05)$ pada taraf signifikansi $5 \%$. Besarnya korelasi rxy = 0,866 dengan koefisien determinasi sebesar 75\%; artinya kecerdasan logika matematika memiliki keterkaitan yang erat dengan hasil belajar matematika dan merupakan salah satu faktor yang mempengaruhi hasil belajar matematika; sementara sisanya dipengaruhi oleh faktor lain.

Siswa SD yang terdapat di Gugus Bajawa I Kecamatan Bajawa Kabupaten Ngada memiliki tingkat kecerdasan logika matematika yang tinggi. Kecerdasan matematis-logis adalah kepekaan pada memahami polapola logis atau numeris, dan kemampuan mengolah alur pemikiran yang panjang. Hal ini berkaitan dengan kemampuan berhitung, menalar, dan berpikir logis, memecahkan masalah (Chatib, 2012: 56). Pendapat lain dikemukakan Uno dan Kudrat (2009: 100) yang menjelaskan bahwa kecerdasan logika matematika berhubungan dengan kegiatan berhitung atau menggunakan angka dalam kehidupan sehari-hari. Selanjutnya Yusuf dan Nurihsan (2010: 230) berpendapat bahwa kecerdasan logika matematika merupakan kecerdasan yang meliputi kemampuan menjumlahkan secara matematis, berpikir secara logis, mampu berpikir secara deduktif dan induktif serta ketajaman dalam membuat pola-pola dan hubungan-hubungan yang logis. Inteligensi ini berhubungan erat dengan ilmu pengetahuan dan logika. 
Dari pengertian yang dijelaskan di atas, disimpulkan bahwa kecerdasan logika matematika sangat berkaitan erat dengan hasil belajar matematika. Berdasarkan data hasil penelitian dan analisis data yang telah dilakukan, dapat diinterpretasikan bahwa terdapat hubungan yang signifikan antara kecerdasan logika matematika dengan hasil belajar matematika siswa yang dibuktikan dengan hasil perhitungan besarnya hubungan atau korelasi antara kecerdasan logika matematika dengan hasil belajar matematika. Setelah dianalisis diperoleh korelasi rxy = 0,866 dengan koefisien determinasi sebesar 75\%; artinya kecerdasan logika matematika memiliki keterkaitan yang erat dengan hasil belajar matematika. Dengan kata lain, kecerdasan logika matematika berhubungan langsung dengan hasil belajar matematika siswa. Kecerdasan logika matematika merupakan salah satu faktor yang mempengaruhi hasil belajar matematika. Selain itu ada juga faktor lain, seperti bakat atau minat, lingkungan belajar, guru, motivasi belajar, ketahanan diri, konsep diri, dan lain-lain.

\section{Simpulan}

Berdasarkan hasil penelitian yang dilakukan di SD Gugus Bajawa I, diperoleh hasil bahwa terdapat hubungan yang signifikan antara kecerdasan logika matematika dengan hasil belajar matematika. Besarnya hubungan atau korelasi antara antara kecerdasan logika matematika dengan hasil belajar matematika setelah dianalisis diperoleh korelasi rxy adalah $=0,866$ dengan koefisien determinasi sebesar $75 \%$, artinya kecerdasan logika matematika memiliki keterkaitan yang erat dengan hasil belajar matematika dan merupakan salah satu faktor yang mempengaruhi hasil belajar matematika, sementara sisanya dipengaruhi oleh faktor lain seperti bakat atau minat, lingkungan belajar, guru, motivasi belajar, ketahanan diri, konsep diri, dan lain-lain. Hal ini, menunjukkan bahwa kecerdasan logika matematika memiliki hubungan dengan hasil belajar matematika, dimana jika tingkat kecerdasan logika matematika yang dimiliki siswa tinggi maka hasil belajar matematika siswa juga akan tinggi.

Berdasarkan beberapa temuan yang diperoleh dari penelitian ini, terdapat beberapa saran yang dapat dikemukakan antara lain sebagai berikut. Untuk siswa: hendaknya lebih aktif dalam meningkatkan kemampuan berpikir logis matematis (logika matematika) dalam memecahkan masalah Matematika. Untuk guru: hendaknya menempuh cara-cara alternatif untuk meningkatkan hasil belajar siswa, dengan menggali dan meningkatkan kecerdasan matematis siswa. Karena dengan rangsangan belajar yang intensif dan menarik sehingga menyenangkan, kecerdasan matematis ini bisa dilatih dan ditingkatkan. Untuk sekolah: melalui penelitian ini diharapkan menjadi pedoman bagi sekolah dalam pembelajaran matematika sehingga berguna dalam meningkatkan hasil belajar matematika siswa.

\section{Daftar Pustaka}

Chatib, Munif. 2012. Sekolahnya Manusia. Bandung: Kaifa.

Depdiknas. 2003. Undang-undang No. 20 Sistem Pendidikan Nasional, www.depdiknas.go.id.

Fathani, Abdu Halim dan Masykur Moch. 2007. Mathematical Intelligence : Cara Cerdas Melatih Otak dan Menaggulangi Kesulitan Belajar. Jogjakarta : Ar-Ruzz Media.

Hasbullah. 2011. Dasar-dasar Ilmu Pendidikan. Jakarta : PT Rajagrafindo Persada.

Purwanto, Heri, dkk. 2006. Logika Matematika. Jakarta : PT Ercontara Rajawali.

Sukmadinata, Syaodih Nana. 2012. Metode Penelitian Pendidikan. Bandung: PT Remaja Rosdakarya.

Sundayana, Rostina. 2015. Media dan Alat Peraga dalam Pembelajaran Matematika. Bandung : Alfabeta.

Sudjana, Nana. 2016. Penilaian Hasil Proses Belajar Mengajar. Bandung : PT Remaja Rosdakarya.

Uno B. Hamzah dan Kuadrat Masri. 2009. Mengelola Kecerdasan dalam Pembelajaran. Jakarta: PT Bumi Aksara.

Wewe, Melkior. 2017. The Effect of Problem Based Learning Model and Mathematic-Logical Intelligence Toward Mathematics Learning Achievement Journal of Education Technology. Vol. 1 (1) pp. 7-17. Diunduh 28 Juni 2018

Yusuf, Syamsu. 2010. Psikologi Perkembangan Anak dan Remaja. Bandung : PT Remaja Rosdakarya. 